\title{
Protein Ingredients Control in Gluten Free Products Using SDS-PAGE, Developed Competitive Enzyme Immunoassays and Commercial ELISA Kits
}

\author{
Cellerino Karina ${ }^{1}$, Cagnasso Carolina Elisa ${ }^{1}$, Greco Carola ${ }^{1}$, Docena Guillermo ${ }^{2}$, Polenta Gustavo ${ }^{3}$, \\ Ferreyra Verónica ${ }^{4}$ López Laura Beatriz ${ }^{1}$ \\ ${ }^{1}$ Facultad de Farmacia y Bioquímica, Universidad de Buenos Aires, Buenos Aires, Argentina \\ ${ }^{2}$ Institute of Immunologic and Physiopathologic Studies - IIFP, School of Sciences, National University of La Plata, Buenos Aires, Argentina \\ ${ }^{3}$ National Agricultural Technology Institute (INTA), Buenos Aires, Argentina \\ ${ }^{4}$ Center for Research and Development in Industrialization Technology of Cereals and Oilseeds, National Institute of Industrial Technology, \\ Buenos Aires, Argentina
}

Email address:

kcellerino@ffyb.uba.ar(C. Karina)

\section{To cite this article:}

Cellerino Karina, Cagnasso Carolina Elisa, Greco Carola, Docena Guillermo, Polenta Gustavo, Ferreyra Verónica, López Laura Beatriz. Protein Ingredients Control in Gluten Free Products Using SDS-PAGE, Developed Competitive Enzyme Immunoassays and Commercial ELISA Kits. World Journal of Food Science and Technology. Vol. 2, No. 1, 2018, pp. 12-18. doi: 10.11648/j.wjfst.20180201.12

Received: March 22, 2018; Accepted: April 8, 2018; Published: May 10, 2018

\begin{abstract}
Some protein ingredients declared in the label of gluten free products are allergenic proteins (milk, soy and egg). The proper identification of these proteins in food products is important for consumers who have food allergies. The aim of this study was to control the presence of protein ingredients declared in the label of gluten free products. Samples were analyzed with sodium dodecylsulfate polyacrylamide gel electrophoresis (SDS-PAGE), using an extractive solution of total proteins (Tris-ClH buffer $0.0625 \mathrm{M}$ with 3\% sodium dodecylsulfate and 2\% 2-mercaptoethanol; pH: 6.8) and a selective solvent for the extraction of caseins (isopropanol $55^{\circ}+2$-mercaptoethanol / ISO $+\mathrm{ME}$ ). Developed Competitive enzyme immunoassays were used for the detection / quantification of milk, soy and egg proteins in products elaborated with rice flour. Specific polyclonal rabbit antiserums against milk, soy and egg proteins were used as primary antibodies in these competitive enzyme immunoassays. Commercial ELISA kits from Neogen, R-Biopharm and Romer were used to verify the results. In some samples undeclared allergens were detected. Correct allergens labeling is very important for the safety of allergic consumers. In conclusion, it is possible to identify all the proteins ingredients in these gluten-free foods studied, using a combination of electrophoretic methods and immunochemical methods.
\end{abstract}

Keywords: Protein Ingredients, Allergenic Proteins, Gluten Free Products, SDS-PAGE,

Developed Competitive Enzyme Immunoassays, Commercial ELISA Kit

\section{Introduction}

Food allergies are a growing problem in developing countries but also in emerging countries like Argentina. The main food groups that generate allergic reactions are the "big eight": milk, eggs, soy, wheat, peanuts, nuts, fish and crustaceans [1].

Undeclared allergens in commercial foods are very dangerous for consumers who have food allergies. The clinical symptoms of an allergenic reaction can range from skin and/or gastrointestinal symptoms to anaphylaxis [2].
Food manufacturers must be very carefully in allergen labeling.

There is a need of methodology that enables the detection of allergenic proteins in products. The most common methodology for the analysis of these proteins is ELISA. There are no Latin American companies that produce ELISA kits and in Argentina these kits are very expensive [3].

The aim of this study was to control the presence of protein ingredients in gluten free products. Some of these protein 
ingredients are allergenic proteins (milk, soy and egg). The proper identification of these proteins in food products is important for consumers who have food allergies.

\section{Materials and Methods}

\subsection{Gluten Free Products}

Ten commercial samples were studied. These samples declared the following protein ingredients: corn, sorghum, soy, rice flour; whole egg powder; ovalbumin; dehydrated whole milk and dehydrated potato, manioc starch and soy lecithin. Two batches of gluten free products were analyzed. The description of each product and the list of ingredients present in each of the samples are shown in Table 1.

\subsection{Protein Extraction for SDS-PAGE and Developed Competitive Enzyme Immunoassays}

Total protein extraction was used for SDS-PAGE and Developed Competitive enzyme immunoassays. The extraction buffer was: $0.0625 \mathrm{M}$ Tris- $\mathrm{HCl}(\mathrm{pH}: 6.8)$ containing 3\% sodium dodecyl sulfate (SDS) y $2 \%$ de 2 -mercaptoethanol (2-ME) (Total protein extraction solution). Products $(200 \mathrm{mg}$ ) were extracted adding $2 \mathrm{~mL}$ of total protein extraction solution and heating the mixture in a water bath at $100^{\circ} \mathrm{C}$ for 5 minutes. Then, the mixture was centrifugated at $2500 \mathrm{rpm}$ for 15 minutes. The supernatants were stored at $-20^{\circ} \mathrm{C}$ until the analysis.

A selective extraction solvent (isopropanol $55^{\circ}+$ 2-mercaptoethanol / ISO+ME) was used to evaluate the presence of certain proteins such as caseins with SDS-PAGE. Three hundred and fifty $\mathrm{mg}$ of products were extracted with 2 $\mathrm{mL}$ of ISO+ME. The mixture was shaken using a VirTis Model 23 homogenizer for 5 minutes at medium speed, then each vial was left for 60 minutes standing and shaken for another 5 minutes. The contents of the extraction vessels were transferred to plastic tubes and centrifuged at $3000 \mathrm{rpm}$ for 15 minutes. The supernatants were transferred to Eppendorf tubes and analyzed the same day of extraction.

\subsection{SDS-PAGE}

Protein separation by polyacrylamide slab gel electrophoresis with Laemmli system (SDS-PAGE) was used. [4]

The running gel was prepared with $10 \%$ acrylamide solution in $1.5 \mathrm{M}$ Tris- $\mathrm{HCl}$ containing $0.4 \% \mathrm{SDS}$ (pH: 8.8). The stacking gel was prepared with $3 \%$ solution of acrylamide in $0.5 \mathrm{M}$ Tris- $\mathrm{HCl}$ containing $0.4 \%$ SDS (pH: 6.8).

An aliquot of the extract of dehydrated whole milk, soy or egg $(10 \mathrm{uL})$ was mixed with $30 \mathrm{uL}$ of a solution of $50 \%$ glycerol in water and $30 \mathrm{uL}$ of a solution of $0.001 \%$ bromophenol blue in water. An aliquot of each extract of commercial product $(30 \mathrm{uL})$ was mixed with $15 \mathrm{uL}$ of a solution of $50 \%$ glycerol and $15 \mathrm{uL}$ of a solution of $0.001 \%$ bromophenol blue in water. Five uL of each mixture were load in each well.

Electrophoresis was performed using Tetra Mini Protean cell from BioRad at $180 \mathrm{~V}$ for 45 minutes.
Gel staining was performed with a solution of $0.1 \%$ Coomassie Brilliant Blue R 250 in $40 \%$ methanol and $10 \%$ acetic acid for 30 minutes. The gels were then decolored with an ethanol: acetic acid (40:10) solution in 2 periods of 20 minutes replacing the decolorizing solution with new one the second period. The decolorizing solutions used were discarded. In all cases the gels were preserved in $7 \%$ acetic acid solution with a few drops of dye solution until their analysis, and then dried in a Bio Rad Gelair Dryer.

The densitograms were obtained by transmission with Shimadzu Dual - Wavelength Chromatogram Scanner Model CS - 910 equipment, wavelength of maximum absorption of $550 \mathrm{~nm}$ and of $400 \mathrm{~nm}$ of minimum absorption. Data acquisition was performed with the Chromatography Station CSW program of DataApex Ltd [5]. All the samples were analyzed in duplicate.

\subsection{Immunochemical Methods}

\section{Polyclonal antiserum (primary antibodies):}

Specific polyclonal rabbit antiserums against milk, soy and egg proteins were prepared by inoculating different NZW rabbits with $100 \mu \mathrm{g}$ of milk, soy or egg proteins emulsified with complete Freund's adjuvant. A series of four injections $(50 \mu \mathrm{g})$ of the same antigen in incomplete Freund's adjuvant was administered every 3 weeks. Antibody titres were determined by indirect ELISA.

\subsubsection{Developed Competitive Enzyme Immunoassays to Detect Milk, Soy or Egg Proteins in Products Elaborated With Rice Flour}

Each extract was analyzed in duplicate. The curve had five points $0 ; 0.01 ; 0.03 ; 0.1$ and $0.3 \mu \mathrm{g}$ soy, milk or egg protein / $\mathrm{mL}$ carbonate / bicarbonate buffer, $\mathrm{pH}$ : 9.6. For each point of the curve a dilution of the original extract was performed but the SDS and ME concentration remained constant. In this way the components of the extractive solution were diluted (1: 175 (soy), 1:164 (milk) and 1:260 (egg) with carbonate / bicarbonate buffer, $\mathrm{pH}: 9.6$ ), at all points of the curve. The samples were diluted with carbonate / bicarbonate buffer, $\mathrm{pH}$ : 9.6, in the same way as the points of the curve according to the allergen to be detected.

In previous works the optimum dilution for the primary antibody was selected (1:1250 for soy, 1:12500 for milk and 1:60000 for egg with TBS buffer with $0.1 \% \mathrm{v} / \mathrm{v}$ Tween 20 and $3 \%$ polyethylene glycol ) [6, 7 and not published results]. Seventy five $\mu \mathrm{L}$ of the primary antibody dilution and $75 \mu \mathrm{L}$ of each of the previously prepared curve points or $75 \mu \mathrm{L}$ of the samples extract, were preincubated. In addition, two controls were prepared; a "non-specific control" (NS) containing 200 $\mu \mathrm{L}$ of the buffer used to dilute the primary antibody and a "maximal binding" (M) control containing: $100 \mu \mathrm{L}$ of the buffer used to dilute the primary antibody and $100 \mu \mathrm{L}$ of the diluted primary antibody. Preincubates were stored at $4{ }^{\circ} \mathrm{C}$ in a humid chamber and in darkness for $24 \mathrm{~h}$. Also, an ELISA plate was sensitized by sticking the concentration of antigen (milk, soy and egg) that was previously selected in the optimization test $[6,7$ and not published results]. The sensitized plate was 
incubated in a humid chamber, in the dark at $4^{\circ} \mathrm{C}$ for $24 \mathrm{~h}$. The plate was washed 5 times with wash solution $(0.9 \% \mathrm{w} / \mathrm{v} \mathrm{NaCl}$ and $0.0125 \% \mathrm{v} / \mathrm{v}$ Tween 20 in water). Two hundred $\mu \mathrm{l}$ of blocking solution $(1 \% \mathrm{w} / \mathrm{v}$ bovine gelatin and $0.1 \% \mathrm{v} / \mathrm{v}$ Tween 20 in TBS) were seeded into each well and incubated with shacking for one hour in a humid chamber, in the dark at $37^{\circ} \mathrm{C}$. The plate was washed 5 times with wash solution.

Subsequently, $100 \mu \mathrm{L}$ of the preincubates were seeded in the sensitized/blocked plate. Each plate was incubated for one hour in a humid chamber, in the dark at $37^{\circ} \mathrm{C}$ with shaking. The plate was washed 5 times with wash solution. One hundred $\mu$ of Bio-Rad alkaline phosphatase conjugated Anti-IgG secondary antibody (obtained in goats immunized with purified rabbit $\mathrm{IgG}$ ) was seeded in the wells. The secondary antibody was diluted 1:3000 with TBS buffer with $0.1 \% \mathrm{v} / \mathrm{v}$ Tween 20 and $3 \%$ polyethylene glycol. The plate was incubated again for one hour in a humid chamber, in the dark at $37^{\circ} \mathrm{C}$ with shaking. The plate was washed 5 times with wash solution. Finally, $100 \mu \mathrm{l}$ of a solution containing $1 \mathrm{mg} / \mathrm{mL}$ paranitrophenyl phosphate in a buffer containing $10 \% \mathrm{v} / \mathrm{v}$ diethanolamine and $0.01 \%$ magnesium chloride, $\mathrm{pH}$ : 9.8 were seeded in each well and the plate was incubated 20 minutes more in the dark at $37^{\circ} \mathrm{C}$ with shaking. Absorbance was measured on an ELISA microplate reader (ELISA RT-2100C, Rayto, China) at $405 \mathrm{~nm}$. The absorbance values were corrected with the average absorbance corresponding to the NS. An absorbance calibration curve was constructed: corrected absorbance versus $\ln \mu$ g of milk, soy or egg protein $/ \mathrm{mL}$. By interpolation in the calibration curve, the $\mu \mathrm{g}$ of milk, soy or egg protein / $\mathrm{mL}$ were obtained. This corresponds to the milk, soy or egg content in the diluted extract analyzed. The amount of milk, soy or egg protein in $\mu \mathrm{g} / \mathrm{g}$ of product is calculated according to the following formula:

Amount of protein amount of milk, soy or egg prot.-ug(1)x

In the product $=\frac{\mathrm{V}-\mathrm{uL}(2) \times 1000-\mathrm{mg}(3)}{6.1 \text { or } 5.7 \text { or } 3.8-\mu \mathrm{L}(4) \times \mathrm{P}-\mathrm{mg}(5)}$

(1) $\mu \mathrm{g}$ of milk, soy or egg protein interpolated in the calibration curve.

(2) Volume of supernatant obtained when extracting the product with extractive solution of total proteins: $1000 \mu \mathrm{L}$

(3) $1000 \mathrm{mg}$ : to express the content in $1000 \mathrm{mg}$ of product.

(4) 6.1 or 5.7 or $3.8 \mu \mathrm{L}$. It is the volume of extract that is taken from the $1000 \mu$ of supernatant and diluted 1:175 (soy), 1:164 (milk) and 1:260 (egg). They are brought to $1000 \mu \mathrm{L}$ with Buffer carbonate / bicarbonate; PH 9.6.

(5) P: $200 \mathrm{mg}$. It is the weight of product that is extracted with extractive solution of total proteins.

The detection (LOD) and quantification (LOQ) limits for each developed competitive enzyme immunoassays were: for milk: LOD: $25.0 \mathrm{ppm}$ milk protein, LOQ: $50.0 \mathrm{ppm}$ milk protein. The working range was $13-400 \mathrm{ppm}$ of milk proteins. For soy: LOD: $35.0 \mathrm{ppm}$ soy protein, LOQ: $60.0 \mathrm{ppm}$ soy protein. The working range was $15-420 \mathrm{ppm}$ of soy proteins. For egg: LOD: $6.0 \mathrm{ppm}$ egg protein, LOQ: $16.0 \mathrm{ppm}$ egg protein. The working range was $13-400 \mathrm{ppm}$ of egg proteins.

\subsubsection{Commercial ELISA}

Milk, soy and egg proteins were detected and quantified with different commercial ELISA kits: Neogen, R-Biopharm and Romer kits. All samples were assayed in duplicate following the protocols of each kit.

The detection (LOD) and quantification (LOQ) limits for each kit were: Ridascreen ${ }^{\circledR}$ Fast milk Protein R-Biopharm LOD: $0.7 \mathrm{ppm}$ milk protein and LOQ: $2.5 \mathrm{ppm}$ milk protein with a quantification range of $2.5-67.5 \mathrm{ppm}$ milk protein. Veratox ${ }^{\circledR}$ Allergen Total Milk from Neogen DL: 1 ppm milk protein and LOQ: $2.5 \mathrm{ppm}$ milk protein with a quantification range of 2.5 - $25 \mathrm{ppm}$ milk protein. [8, 9]

Ridascreen ${ }^{\circledR}$ Fast soy Protein R-Biopharm DL: 0.31 ppm soy protein and LOQ: $2.5 \mathrm{ppm}$ soy protein; Romer AgraQuant ${ }^{\circledR}$ Soy Assay LOQ: 16 ppb soy Tripsin Inhibitor and LOQ: 40 ppb soy Tripsin Inhibitor. $[10,11]$

Neogen Veratox ${ }^{\circledR}$ for Egg Allergen LOD: 2,5 ppm egg protein with a quantification range of: $2,5-25$ ppm egg. [12]

\section{Results and Discussion}

Table 1 shows the results of milk, soy and egg protein detection in gluten free foods using SDS-PAGE, Competitive enzyme immunoassays and commercial ELISA kits.

In most of the samples that were analyze, the protein ingredients of corn, sorghum, rice, egg, ovalbumin, potato, soy and milk were identified with the SDS-PAGE methodology, using extractive protein solution. In two samples the presence of rice proteins was presumed, although it was not evident $(9 \mathrm{y}$ 10). In addition, in six of the samples that presented a complex electrophoretic profile, the presence of milk or soy proteins was not evident $(2,3,4,6,7,9)$. In order to confirm the presence of milk, these samples were analyzed by SDS-PAGE using ISO $+\mathrm{ME}$ as extraction solvent. The SDS-PAGE methodology with ISO + ME allowed not only to confirm the presence of milk proteins but also the presence of sorghum proteins in the samples that contained them $(2,4,5,6,7$ and 8).

As an example figure 1 shows densitograms of samples 1, 2 and 8 . In sample 1 soy, corn and sorghum peaks are evident (So, $\mathrm{S}$ and $\mathrm{C}$ ). In sample 2 egg, milk, soy, rice and sorghum peaks can be detected (E, M, So, R and S). Ovalbumin, rice and sorghum can be distinguished in sample $8(\mathrm{O}, \mathrm{R}$ and $\mathrm{S})$. 

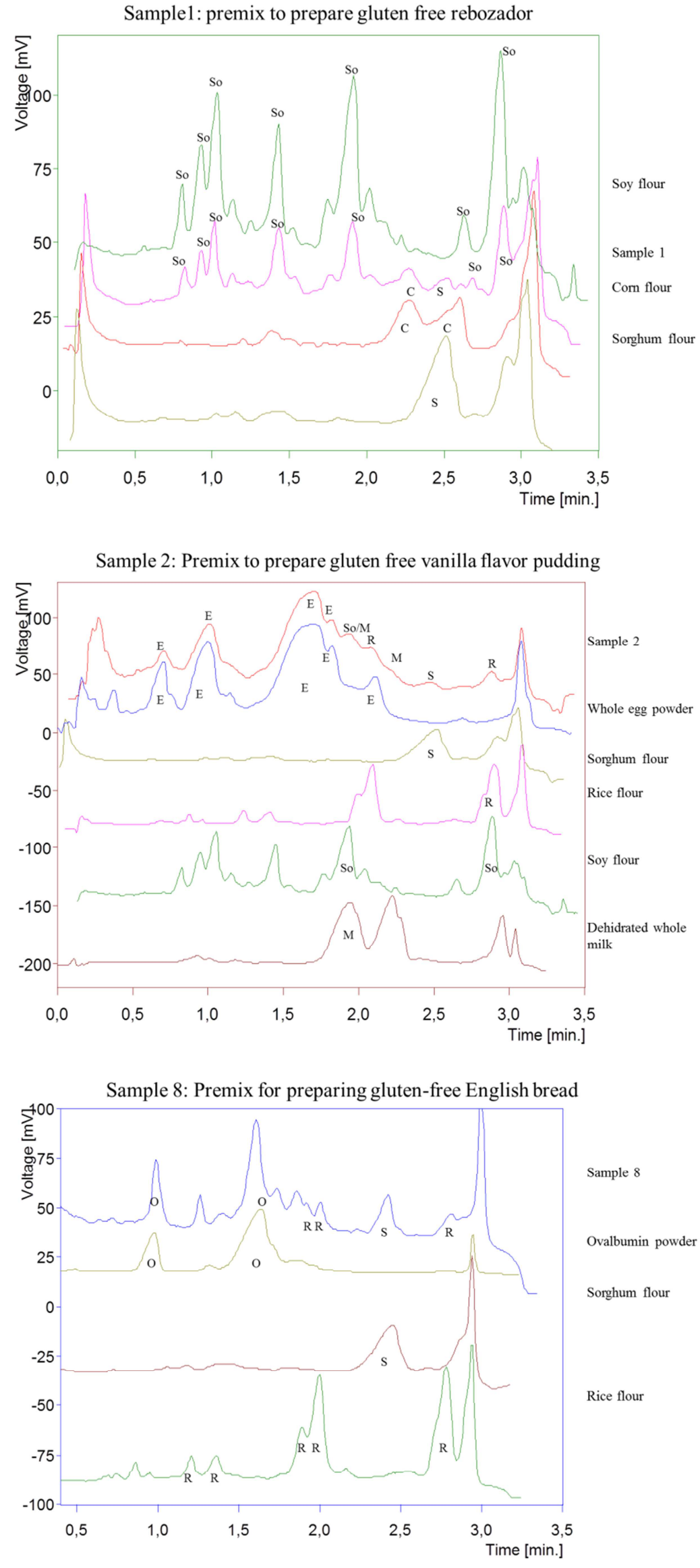

Figure 1. Densitograms of total proteins in samples 1, 2 y 8 and standards. 
In most of the samples, the presence of milk, soy or egg proteins that were identified using SDS- PAGE, were verified with the developed competitive enzyme immunoassays. Commercial ELISA kits were used to corroborate these results.

In the analyzed samples that declared milk, soy and egg, developed competitive enzyme immunoassays and the commercial ELISA kits detected those proteins (samples 2, 3, 4, 6, 7 and 9). In a sample that did not declare milk or egg, developed competitive enzyme immunoassays detected milk and egg protein. This was corroborated using commercial ELISA kits (sample 1). In two samples that did not declare soy, the developed competitive enzyme immunoassays detected soy protein; this was corroborated using the commercial ELISA kit (samples 8 and 10). In a sample that did not declare milk, the developed competitive enzyme immunoassays did not detect milk proteins, however, they were detected and quantified using the commercial ELISA kits (sample 8). These results are due to the different sensitivity of both methodologies used.

It has been observed in several studies that the results between different ELISAs may be dissimilar. In order to detect the presence of extrinsic proteins an ELISA is often the method of choice because they are considered to have high sensitivity and specificity. Although ELISA method is accepted as standard method for allergen measurement, the results obtained by this methodology seemed to vary from assays to assays. This variation could be due to the lack of standardization of the method, the calibration material used, the extraction solutions used or the antibody specificity $[13,14]$. Therefore the quantitative results between developed competitive enzyme immunoassays and commercial ELISA kits cannot be compared.

The significance of the developed competitive enzyme immunoassays that were developed is that their sensibility is higher than the sensibility of the SDS-PAGE and also it allows quantification of the allergens.

SDS-PAGE is the suggested method if it is suspected that allergens proteins were added as an ingredient. The developed competitive enzyme immunoassays that were developed by our work group could be used as a screening method, in cases that it is suspected that allergenic proteins may be present by cross-contact. The cost of the developed competitive enzyme immunoassays was calculated in December 2017 and it was 0.50 U.S dollars per well. At the same time a commercial kit had a market value of 10.30 U.S. dollars per well in Argentina. So the developed competitive enzyme immunoassays has a considerably lower cost than commercial ELISA kits. If a sample shows a positive result with the developed competitive enzyme immunoassays, it is not necessary to use a commercial ELISA kit because the sample contains the allergen. If negative results are obtained with this methodology, it should be confirmed with a commercial ELISA kit of adequate sensitivity, to ensure the absence of allergens proteins.

In different samples that were analyzed and did not declare some proteins, the developed competitive enzyme immunoassays detected those proteins and this was corroborated using the commercial ELISA kits. The presence of these undeclared proteins is a risk for allergic consumers. According to previous studies there are a lot of foods that have a high risk of containing undeclared allergens and may lead to product recalls or to potential hazards. Many studies found higher prevalence of undeclared allergens with or without advisory statement. [14]

\section{Conclusions}

In conclusion, it is possible to identify all the proteins ingredients in these gluten-free foods studied, using a combination of electrophoretic methods and immunochemical methods.

In some samples undeclared allergens were detected. Correct allergens labeling is very important for the safety of allergic consumers. A correct labeling would be possible if food manufacturers and official food control laboratories had at their disposal methodologies to detect the allergenic proteins.

Table 1. Detection of milk, soy and egg proteins using SDS-PAGE, developed competitive enzyme immunoassay and different commercial ELISA kits in two batches of gluten free products.

\begin{tabular}{|c|c|c|}
\hline Sample & Ingredients/allergens declarations & $\begin{array}{l}\text { SDS-PAGE Total } \\
\text { proteins detected }\end{array}$ \\
\hline $\begin{array}{l}1 \\
\text { Premix to prepare gluten free } \\
\text { breadcrumbs }\end{array}$ & $\begin{array}{l}\text { Corn flour, sorghum flour, soy flour, salt. } \\
\text { Contains soy }\end{array}$ & $\begin{array}{l}\text { Soy } \\
\text { Corn } \\
\text { Sorghum }\end{array}$ \\
\hline $\begin{array}{l}2 \\
\text { Premix to prepare gluten free } \\
\text { vanilla flavor pudding }\end{array}$ & $\begin{array}{l}\text { Sugar, whole egg powder, sorghum flour, corn starch, rice flour. Emulsifiers: mono and } \\
\text { diglycerides of lactic acid and propylene glycol. Soy flour, dehydrated whole milk. } \\
\text { Chemical leavenings (sodium bicarbonate, sodium acid pyrophosphate and monocalcium } \\
\text { phosphate). Vanilla flavoring. } \\
\text { Contains egg, milk and soy }\end{array}$ & $\begin{array}{l}\text { Egg } \\
\text { Rice } \\
\text { Sorghum } \\
\text { Milk? } \\
\text { Soy? }\end{array}$ \\
\hline $\begin{array}{l}3 \\
\text { Premix to prepare gluten-free } \\
\text { pancakes. }\end{array}$ & $\begin{array}{l}\text { Rice flour, whole egg powder, sorghum flour, corn starch, dehydrated whole milk, soy } \\
\text { flour, salt. } \\
\text { Contains egg, milk and soy }\end{array}$ & $\begin{array}{l}\text { Egg } \\
\text { Rice } \\
\text { Sorghum } \\
\text { Milk } \\
\text { Soy? } \\
\text { Egg } \\
\text { Potato } \\
\text { Rice } \\
\text { Sorghum } \\
\text { Milk } \\
\text { Soy? }\end{array}$ \\
\hline
\end{tabular}




\begin{tabular}{|c|c|c|}
\hline Sample & Ingredients/allergens declarations & $\begin{array}{l}\text { SDS-PAGE Total } \\
\text { proteins detected }\end{array}$ \\
\hline 5 & & Soy \\
\hline $\begin{array}{l}\text { Premix based on rice flour, sor- } \\
\text { ghum flour and corn starch for } \\
\text { gluten-free bakery and pastry }\end{array}$ & $\begin{array}{l}\text { Rice flour, sorghum flour, corn starch, dehydrated whole milk, soy flour, salt. } \\
\text { Contains milk and soy }\end{array}$ & $\begin{array}{l}\text { Sorghum } \\
\text { Mlik } \\
\text { Rice }\end{array}$ \\
\hline $\begin{array}{l}6 \\
\text { Premix to prepare sweet cookies } \\
\text { and free gluten-free chips. }\end{array}$ & $\begin{array}{l}\text { Sugar, rice flour, sorghum flour, corn starch, dehydrated whole milk, soy flour, whole egg } \\
\text { powder. Chemical leavenings (sodium bicarbonate, sodium acid pyrophosphate). Vain- } \\
\text { illina flavoring. } \\
\text { Contains egg, milk and soy }\end{array}$ & $\begin{array}{l}\text { Egg } \\
\text { Rice } \\
\text { Sorghum } \\
\text { Milk? } \\
\text { Soy }\end{array}$ \\
\hline $\begin{array}{l}7 \\
\text { Premix to prepare gluten-free } \\
\text { vanilla flavor sponge cake. }\end{array}$ & $\begin{array}{l}\text { Sugar, whole egg powder, rice flour, sorghum flour, corn starch. Emulsifiers: mono and } \\
\text { diglycerides of lactic acid and propylene glycollester. Dehydrated whole milk, soy flour. } \\
\text { Vanilla flavoring. Chemical leavenings (sodium acid pyrophosphate, sodium bicarbonate } \\
\text { and monocalcium phosphate). Contains egg, milk and soy }\end{array}$ & $\begin{array}{l}\text { Egg } \\
\text { Rice } \\
\text { Sorghum } \\
\text { Milk? } \\
\text { Soy? }\end{array}$ \\
\hline $\begin{array}{l}8 \\
\text { Premix to prepare gluten-free } \\
\text { English bread }\end{array}$ & $\begin{array}{l}\text { Corn starch, sorghum flour, rice flour, sugar, ovalbumin powder, salt, stabilizers (xanthan } \\
\text { gum and carboxymethylcellulose), fungal alfa amylase. Contains egg }\end{array}$ & $\begin{array}{l}\text { Ovoalbumin/conalbumin } \\
\text { Sorghum } \\
\text { Rice } \\
\text { Egg }\end{array}$ \\
\hline $\begin{array}{l}9 \\
\text { Premix to prepare gluten-free egg } \\
\text { pasta. }\end{array}$ & $\begin{array}{l}\text { Rice flour, sorghum flour, corn starch, whole egg powder, dehydrated whole milk, soy } \\
\text { flour, salt. Stabilizer: xanthan gum. } \\
\text { Contains egg, milk and soy }\end{array}$ & $\begin{array}{l}\text { Rice? } \\
\text { Sorghum } \\
\text { Milk? } \\
\text { Soy? }\end{array}$ \\
\hline $\begin{array}{l}10 \\
\text { Premix to prepare gluten-free } \\
\text { pizza. }\end{array}$ & $\begin{array}{l}\text { Corn starch, sorghum flour, rice flour, dextrose, dehydrated whole milk. Emulsifiers: mono } \\
\text { and diglycerides of lactic acid and propilenglicolester. Ovalbumin powder, salt. Stabilizers: } \\
\text { xanthan gum. Chemical leaners: sodium acid pyrophosphate and sodium bicarbonate. } \\
\text { Contains egg and milk }\end{array}$ & $\begin{array}{l}\text { Ovoalbumin/conalbumin } \\
\text { Sorghum } \\
\text { Milk } \\
\text { Rice? }\end{array}$ \\
\hline
\end{tabular}

Table 1. Continued

\begin{tabular}{|c|c|c|c|c|}
\hline Sample & $\begin{array}{l}\text { SDS-PAGE ISO + ME } \\
\text { proteins detected }\end{array}$ & $\begin{array}{l}\text { Competitive ELISA (CE) } \\
\text { Neogen (N) R-Biopharm } \\
\text { Milk (R-B) }\end{array}$ & $\begin{array}{l}\text { Competitive ELISA (CE) } \\
\text { Romer(R) R-Biopharm } \\
\text { Soy (R-B) } \\
\end{array}$ & $\begin{array}{l}\text { Competitive ELISA (CE) } \\
\text { Neogen Egg (N) }\end{array}$ \\
\hline 1 & & CE: $>400 / 280$ & & \\
\hline $\begin{array}{l}\text { Premix to prepare gluten free } \\
\text { breadcrumbs }\end{array}$ & -- & $\begin{array}{l}\mathrm{N}:>25 / 10 \\
\mathrm{R}-\mathrm{B}:>67.5 / 17.1\end{array}$ & $\begin{array}{l}\mathrm{CE}:>420 />420 \\
\mathrm{R}:>1000 />1000\end{array}$ & $\begin{array}{l}\mathrm{CE}:>400 />400 \\
\mathrm{~N}:>25 />25\end{array}$ \\
\hline $\begin{array}{l}2 \\
\text { Premix to prepare gluten free } \\
\text { vanilla flavor pudding }\end{array}$ & $\begin{array}{l}\text { Milk } \\
\text { Sorghum }\end{array}$ & $\begin{array}{l}\mathrm{CE}:>400 />400 \\
\mathrm{R}-\mathrm{B}:>67.5 />67.5\end{array}$ & $\begin{array}{l}\mathrm{CE}:>420 />420 \\
\mathrm{R}:>1000 />1000\end{array}$ & $\begin{array}{l}\mathrm{CE}:>400 />400 \\
\mathrm{~N}:>25\end{array}$ \\
\hline 3 & --- & $\begin{array}{l}\text { CE: }>400 \\
\text { R-B: }>67.5 \mathrm{ppm}\end{array}$ & $\begin{array}{l}\mathrm{CE}:>420 \\
\mathrm{R}:>1000\end{array}$ & $\begin{array}{l}\mathrm{CE}:>400 \\
\mathrm{~N}:>25\end{array}$ \\
\hline $\begin{array}{l}\text { pancakes. } \\
4 \\
\text { Premix to prepare gluten-free } \\
\text { gnocchi. }\end{array}$ & $\begin{array}{l}\text { Milk } \\
\text { Sorghum }\end{array}$ & $\begin{array}{l}\mathrm{CE}:>400 />400 \\
\mathrm{R}-\mathrm{B}:>67.5 />67.5\end{array}$ & $\begin{array}{l}\text { CE: }>420 />420 \\
\text { R: }>1000 />1000 \\
\text { R-B: }>20\end{array}$ & $\begin{array}{l}\mathrm{CE}:>400 />400 \\
\mathrm{~N}:>25\end{array}$ \\
\hline 5 & & & & \\
\hline $\begin{array}{l}\text { Premix based on rice flour, sor- } \\
\text { ghum flour and corn starch for } \\
\text { gluten-free bakery and pastry }\end{array}$ & $\begin{array}{l}\text { Milk? } \\
\text { Sorghum }\end{array}$ & $\begin{array}{l}\text { CE: }>400 \\
\text { R-B: }>67.5\end{array}$ & --- & $\begin{array}{l}\text { CE: } 305 \\
\mathrm{~N}:>25\end{array}$ \\
\hline $\begin{array}{l}6 \\
\text { Premix to prepare sweet cookies } \\
\text { and free gluten-free chips. }\end{array}$ & $\begin{array}{l}\text { Milk } \\
\text { Sorghum }\end{array}$ & $\begin{array}{l}\text { CE: }>400 \\
\text { R-B: }>67.5\end{array}$ & --- & $\begin{array}{l}\text { CE: }>400 \\
\mathrm{~N}:>25\end{array}$ \\
\hline $\begin{array}{l}7 \\
\text { Premix to prepare gluten-free } \\
\text { vanilla flavor sponge cake. }\end{array}$ & $\begin{array}{l}\text { Milk } \\
\text { Sorghum }\end{array}$ & $\begin{array}{l}\mathrm{CE}:>400 />400 \\
\mathrm{R}-\mathrm{B}:>67.5 />67.5\end{array}$ & $\begin{array}{l}\mathrm{CE}:>420 />420 \\
\mathrm{R}:>1000 />1000\end{array}$ & $\begin{array}{l}\mathrm{CE}:>400 />400 \\
\mathrm{~N}:>25\end{array}$ \\
\hline $\begin{array}{l}8 \\
\text { Premix to prepare gluten-free } \\
\text { English bread }\end{array}$ & Sorghum & $\begin{array}{l}\text { CE: }<50 \\
\text { R-B: } 36.6 \\
N:>25\end{array}$ & $\begin{array}{l}\text { CE: } 99 / 75 \\
\text { R: }>1000 / 173 \\
\text { R-B: }>20\end{array}$ & $\begin{array}{l}\mathrm{CE}:>400 />400 \\
\mathrm{~N}:>25 />25\end{array}$ \\
\hline $\begin{array}{l}9 \\
\text { Premix to prepare gluten-free egg } \\
\text { pasta. }\end{array}$ & -- & $\begin{array}{l}\text { CE: }>400 \\
\text { R-B: }>67.5\end{array}$ & CE: $>420$ & $\begin{array}{l}\mathrm{CE}:>400 \\
\mathrm{~N}:>25\end{array}$ \\
\hline $\begin{array}{l}10 \\
\text { Premix to prepare gluten-free } \\
\text { pizza. }\end{array}$ & -- & $\begin{array}{l}\mathrm{CE}:>400 />400 \\
\mathrm{R}-\mathrm{B}:>67.5 />67.5\end{array}$ & $\begin{array}{l}\text { CE: }>420 />420 \\
\text { R: } 668 / 761 \\
\text { R-B: }>20 />20\end{array}$ & $\begin{array}{l}\mathrm{CE}:>400 />400 \\
\mathrm{~N}:>25 />25\end{array}$ \\
\hline
\end{tabular}




\section{Acknowledgements}

This work was partially financiated by the Buenos Aires University (UBACYT 20020160100060BA).

\section{References}

[1] Ward R. 2014. Chapter 1: Introduction to food aller-gy. In Flanagan S, Handbook of Food Allergen Detection and Control. Woodhead Publishing. Cambridge, UK.

[2] Koeberl M., Clarke D., Allen K. J, Fleming F., Katzer L., Lee N. A., Lopata A. L., Said M., Scheelings p., Shepherd N., Sherlock R., Roberts J. 2018. Food Allergens Management in Australia. Journal of AOAC International. 101(1):60-69(10). DOI: https://doi.org/10.5740/jaoacint.17-0386

[3] López M. C. 2018. Food Allergen Labeling: A Latin American Approach. Journal of AOAC International. 101(1):14-16(3). DOI: https://doi.org/10.5740/jaoacint.17-0382

[4] Laemmli U. 1970. Cleavage of structural protein during the assembly of the head of bacteriophage T4. Nature. 227: 680-685.

[5] López L. B. 2000. Separation, identification and quan-tification of proteins in processed foods. Thesis UBA. Argentina.

[6] Cellerino K. 2016. Control Methodology for the analysis of milk, soy and egg allergens in meat and farinaceous products. Thesis UBA. Argentina.
[7] Cellerino K., Rodríguez V., Docena G., López L. B. 2017. Development of a Competitive Enzyme Immunoassay Technique for the Detection of Soy Traces in Meat Products. Journal of Food and Nutrition Sciences. 5(2): 57-62. Doi: 10.11648/j.jfns.20170502.16

[8] R-Biopharm RIDASCREEN® FAST Milk. 2009. https://food.r-biopharm.com/wp-content/uploads/sites/2/2015/ 09/R4652-FAST-Milk-15-07-09.pdf. Access: january 2018.

[9] Neogen Veratox ${ }^{\circledR}$ for Total milk allergen. 2016. http://foodsafety.neogen.com/pdf/procedures/8470_pro.pdf Access: january 2018.

[10] R-Biopharm RIDASCREEN® FAST Soya. 2018. https://food.r-biopharm.com/wp-content/uploads/sites/2/2016/ 10/R7102-FAST-Soya-16-07-18.pdf. Access: january 2018.

[11] Romer AgraQuant ${ }^{\circledR}$. Soy Assay. 2011. http://shop.romerlabs.com/en/AgraQuant-ELISA/AgraQuantAllergens/AgraQuant-ELISA-Soy. Access: january 2018.

[12] Neogen Veratox ${ }^{\circledR}$ for Egg Allergen. 2013. http://foodsafety.neogen.com/en/veratox-egg. Access: january 2018.

[13] Diaz Amigo C. 2010. Towards a Comprehensive Validation of ELISA Kits for Food Allergens. Case 2- Milk. Food Analytical Methods. 3: 351-356.

[14] Do A. B, Khuda S. E, Sharma M. G. 2018. Undeclared food allergens and gluten in commercial food products analyzed by ELISA. Journal of AOAC International. 101(1):23-35(13). DOI: https://doi.org/10.5740/jaoacint.17-0384 